\title{
Characteristics of High Energy Collision-Induced Dissociation Tandem Mass Spectra of Polycyclic Aromatic Hydrocarbon Diolepoxide Adducted Peptides
}

\author{
Joseph Zaia and Klaus Biemann \\ Department of Chemistry, Massachusetts Institute of Technology, Cambridge, Massachusetts, USA
}

\begin{abstract}
Polycyclic aromatic hydrocarbon (PAH) diolepoxides are known to covalently modify serum albumin and hemoglobin. Mass spectrometric techniques have proven quite useful in the characterization of the site of adduction on these proteins. To facilitate the study of PAH diolepoxide adducted peptides, model peptide adducts of benzo[a]pyrene-trans-7,8-dihydrodiol-9,10-epoxide [anti-BaP(9,10)DE] and benzol a] anthracene-trans-8,9-dihydrodiol-10,11epoxide $[$ anti-BaA(10,11)DE] have been synthesized for the purpose of studying their high energy collision-induced dissociation tandem mass spectra. These spectra are dominated by ions produced from cleavage of the peptide-adduct bond with charge retention by the adducting moiety. Such ions allow for the facile identification of adducted peptides in a mixture by use of neutral loss scans. The peptide sequence can still be deduced from the data in most cases, and the site of adduction can be determined. For those peptide-adducts in which this is not possible, a charged derivative placed at the $\mathrm{N}$-terminus simplifies the peptide fragmentation pattern and makes the spectrum more interpretable. (J Am Soc Mass Spectrom 1994, 5, 649-654)
\end{abstract}

A number of polycyclic aromatic hydrocarbon (PAH) compounds have demonstrated carcinogenic activity [1]. They are major petroleum constituents and are found in the environment wherever fossil fuels have been spilled. PAHs are also produced during combustion of fossil fuels $[2,3]$ and are, therefore, sources of air pollution. Gas-phase dispersal has resulted in detectable levels of PAH in areas remote from sources of pollution [4]. The effects of these compounds are of major human health and environmental concern [5].

Once ingested, the PAH is metabolized, predominantly in the liver, by the cytochrome P450 systems (for a review see ref 6 ). This metabolism involves a series of reactive intermediates formed by a multistep oxidation process. The bulk of the reactive species are deactivated by various mechanisms to soluble nonelectrophilic metabolites that are excreted. However, some of these species may react with nucleic acids and proteins (for a review see ref 7). Reaction of carcinogens with DNA generally is believed to be the initiating event that results in the formation of tumors. Reaction with proteins, on the other hand, is thought to be one of the mechanisms whereby a chemical exerts its toxic effects on the cell [8]. The reactions of

Address reprint requests to Dr. Klaus Biemann, Department of Chemistry, Room 56-010, Massachusetts Institute of Technology, Cambridge, MA 02139-4307. carcinogens with proteins are of inlerest for studies of the basic mechanisms of carcinogen interactions [8] and for molecular dosimetry $[9,10]$. Two pathways that result in the metabolic activation of PAH have been described in the literature: the diolepoxide pathway [11] and the one-electron oxidation pathway [12-14].

Recently, mass spectrometric techniques were used in the identification of covalent benzo[a]pyrene-trans7,8-dihydrodiol-9,10-epoxide [anti-B $a \mathrm{P}(9,10) \mathrm{DE}]$ (Structure I) adducts of serum albumin [15] and hemoglobin [16, 17]. The collision-induced dissociation (CID) mass spectra of tetrapeptides and pentapeptides isolated from fluoranthene-hemoglobin (rat) adducts were reported and briefly discussed without mass spectrometric assignment of the site of attachment of the fluoranthene diolepoxide [18]. The reaction of styrene oxide with human hemoglobin was shown by CID mass spectrometry to take place at $\alpha$-His -4 and $\beta$-His-143 [19]. In this case, where the adducting moiety is relatively small (1-phenyl-1-hydroxy-ethyl), the CID spectra are identical to those of the unmodified peptide except for a mass shift of $130 \mathrm{u}$ for the fragments including the modification. However, large polycyclic aromatic adduct moieties have a dramatic effect on the CID spectra of the modified peptides as briefly reported earlier [20].

A detailed study of the CID spectra of peptides that have been adducted with either of two diolepoxides, 


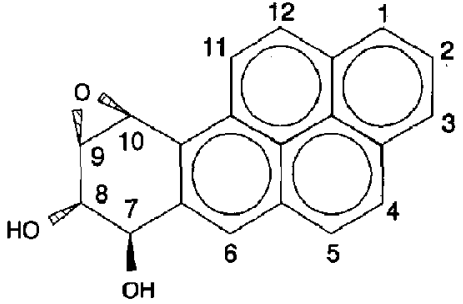

I

anti-B $a \mathrm{P}(9,10) \mathrm{DE}$ or benzo[ $a$ ]anthracene-trans8,9-dihydrodiol-10,11-epoxide [anti-BaA(10,11)DE] (Structure II) is the subject of this investigation. Anti$\mathrm{B} a \mathrm{P}(9,10) \mathrm{DE}$ adducts with serum albumin have shown modification at histidine [15]; therefore, adducts with histidine as the site of modification have been used as model compounds for the CID tandem mass spectrometry studies in this work. The term "adduct" refers to the covalently modified peptide. Anti-BaP(9,10)DE is a "bay-region" diolepoxide, whereas anti-B $a \mathrm{~A}(10,11) \mathrm{DE}$ does not belong to this category [21]. A bay-region diolepoxide hydrolyzes to form a cation, which is more stable than the cation formed from a nonbay-region diolepoxide, an effect that is thought to play a role in the carcinogenicity of bay-region diolepoxides [22-23].

Although this article deals with the tandem mass spectra of peptides substituted with a PAH triol moiety, it should be noted that mass spectrometric investigations of reaction products of PAHs [13] with guanosine and amino-PAHs [24, 25] with guanosine and/or adenosine have been reported, including their tandem mass spectra.

\section{Materials and Methods}

Benzo[a]pyrene-trans-7,8-dihydrodiol-9,10-epoxide (anti) and benzo[ $a]$ anthracene-trans-8,9-dihydrodiol10,11-epoxide (anti) were purchased from the National Cancer Institute Chemical Carcinogen Repository operated by Midwest Research Institute (Kansas City, MO). All peptides, iodoacetic anhydride, and 2-( $\mathrm{N}$-morpholino)ethanesulfonic acid (MES) buffer were purchased from Sigma Chemical Co. (St. Louis, MO) and used without further purification. Dry tetrahydrofuran (THF) and trimethylamine ( $25 \mathrm{wt} \%$ aqueous solution) were purchased from Aldrich Chemical Co. (Milwau-

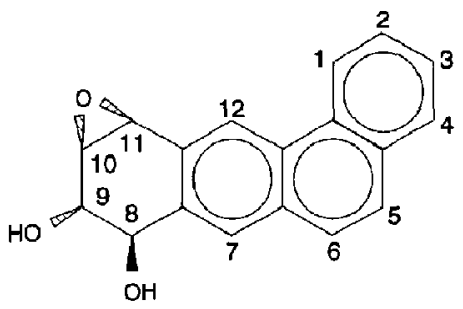

II kee, WI). The semipreparative C4 protein reversedphase high-performance liquid chromatography (HPLC) column $(1 \times 25 \mathrm{~cm})$ was purchased from $\mathrm{Vy}-$ dac Separations Group (Hesperia, CA).

\section{Mass Spectrometry}

Fast-atom bombardment (FAB) mass spectrometry was carried out in the first (MS-1) of two mass spectrometers of a tandem mass spectrometer (JEOL [Tokyo] $\mathrm{HX110/HX110)}$ operating at an accelerating voltage of $10 \mathrm{kV}$ and a resolution of $1: 1000$ or $1: 2600$. Single scans were acquired at a rate of $\mathrm{m} / z 0-6000$ in $1.0 \mathrm{~min}$, with $100-300-\mathrm{Hz}$ filtering and the electron multiplier set at $1.0 \mathrm{kV}$. ( $\mathrm{CsI})_{n} \mathrm{CsI}^{+}$cluster ions were used for the calibration. A JEOL $\mathrm{Cs}^{+}$gun was used at $26 \mathrm{kV}$. The sample ( $\sim 12 \mathrm{nmol}$ in $0.5-\mu \mathrm{L} \mathrm{H}_{2} \mathrm{O}$ ) was mixed with glycerol $(0.2 \mu \mathrm{L})$ on the probe tip. The volume of the sample-glycerol mixture was reduced by using a vacuum chamber, after which thioglycerol $(0.5 \mu \mathrm{L})$ was added. The probe was then placed into the ion source of the mass spectrometer.

Tandem mass spectrometry was performed on the JEOL HX110/HX110 double focusing tandem mass spectrometer, which is of $E_{1} B_{1} E_{2} B_{2}$ configuration. Collision-induced dissociation of the protonated peptide molecule $\left({ }^{12} \mathrm{C}\right.$ monoisotopic ion) selected with MS-1 took place in the field-free region after $B_{1}$. The collision cell potential was $3.0 \mathrm{kV}$ and the ion collision energies were $7.0 \mathrm{keV}$. Helium, the collision gas, was introduced into the collision chamber to reduce the precursor ion signal by $65-70 \%$. The second mass spectrometer (MS-2) was scanned from $m / z 30$ to $20 \mathrm{u}$ above the mass-to-charge ratio of the precursor ion by using $100-\mathrm{Hz}$ filtering and a scan rate corresponding to $\mathrm{m} / \mathrm{z}^{0} \mathrm{0}-6000$ in $1.5 \mathrm{~min}$. Two scans were summed for each spectrum. MS-2 was operated at 1:1000 resolution and was calibrated with a mixture of CsI, NaI, KI, RbI, and $\mathrm{LiCl}$ [26].

Neutral loss scans were performed with MS-1 resolution set at 1:1000 by using a grounded collision cell located behind the ion source of MS-1. The ion signal was reduced by approximately $70 \%$ by using helium gas. A single scan was acquired with the electron multiplier set at $1.5 \mathrm{kV}$.

\section{Preparation of PAH-Diolepoxide Adducted Synthetic Peptides}

The anti-B $a \mathrm{P}(9,10) \mathrm{DE}$-histidine adduct was prepared by Day et al. [15]. Adducted peptides were prepared as follows. The peptide of interest $(25 \mathrm{mg})$ was dissolved in a minimum volume $(2-4 \mathrm{~mL})$ of $0.1-\mathrm{M}$ sodium phosphate buffer, $\mathrm{pH} 7.0$, to which was added $1 \mathrm{mg}$ of the diolepoxide (freshly dissolved in $100-\mu \mathrm{L}$ dry $\mathrm{THF}$ ). The mixture was incubated rocking for $2 \mathrm{~h}$ at $37{ }^{\circ} \mathrm{C}$. The product was acidified with acetic acid, filtered, and loaded onto a semipreparative (1- $\times 25$ - 
cm) C4 reversed-phase column. The material was eluted with a linear gradient of $0-60 \%$ acetonitrile, 2 $\mathrm{mL} / \mathrm{min}$, in the presence of TFA. The unadducted peptide eluted as a very broad peak, after which the adducted peptide eluted. The adducted peptide was identified by its molecular weight deduced from its FAB mass spectrum in the normal mode.

\section{Preparation of Trimethylammoniumacetyl Derivatives of anti-Ba $P(9,10) D E$ Adducted Peptides}

This derivative was prepared by modification of the method of Wetzel et al. [27]. The peptide $(\sim 10 \mathrm{nmol})$ was dissolved in a $100-\mu \mathrm{L}$ solution of $1: 1$ (buffer:methanol) 0.1-M MES ( $\mathrm{pH}$ 6.0) and reacted on ice with repeated $(10-12 \times, 3$-min intervals) aliquots ( $0.5 \%$ by volume) of the iodoacetic anhydride in THF (0.4 M, dry THF, stored desiccated under argon in a laboratory freezer). Trimethylamine (25 $\mathrm{wt} \%$ aqueous solution) was added ( $5 \%$ by volume) and allowed to react with the iodoacetylated peptide for $30 \mathrm{~min}$ at room temperature. The reaction was acidified with acetic acid, desalted on a short reversed-phase HPLC column, and dried in a centrifugal evaporator. The peptide was dissolved in water on the day the mass spectra were acquired and mixed with thioglycerol over a thin layer of glycerol on the probe tip.

\section{Results and Discussion}

The CID spectra of anti-BaP( $(9,10) \mathrm{DE}$ adducted peptides are dominated by product ions derived from the adducting moiety. The CID spectrum of histidine adducted at an imidazole nitrogen with anti-BaP(9,10)DE is shown in Figure 1. The stability of the C-10 carbocation $[22,23]$ may trigger the heterolytic cleavage of the bond between the adduct and the histidine ring (Scheme 1). The assignment of the bond to $\mathrm{N}^{\tau}$ rather than $N^{\pi}$ is made in analogy to earlier work [15]. The

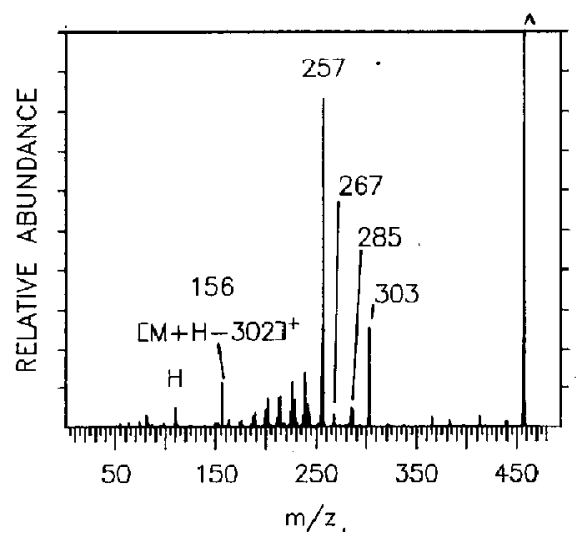

Figure 1. CID tandem mass spectrometry spectrum of the histidine anti-BaP(9,10)DE adduct, $[\mathrm{M}+\mathrm{H}]^{+}=m / z$ 458.2.

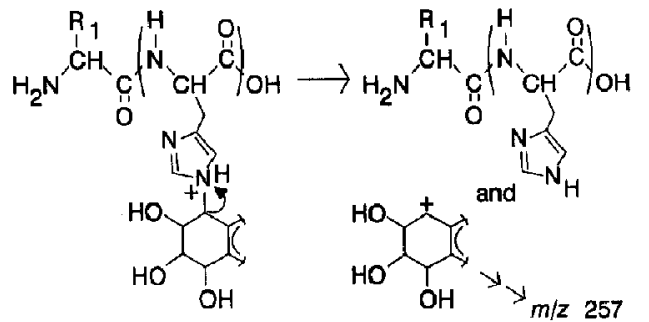

Scheme 1. Mechanism for the production of ions from the adducting moiety of anti-B $a \mathrm{P}(9,10) \mathrm{DE}$ adducts. An analogous mechanism applies for other PAH diolepoxide adducts. The $\mathrm{N}^{\tau}$ adduct is shown in accordance with the finding of earlier work on serum albumin adducts [15].

resulting ion of $m / z 303$ then fragments further (Scheme 2) to other well stabilized cations, of which the smallest, $m / z 257$, predominates. It should be noted that the CID spectra of adducts of I to guaninosine and adeninosine are also dominated by peaks of $m / z$ 303, 285, and 257 (most abundant) [13]. The peak at $m / z 156$ in Figure 1 corresponds to protonated histidine, which is formed by the loss of the triol moiety as an epoxide (i.e., the reverse of the adduct formation) as shown in Scheme 3 for a dipeptide. This fragmentation is apparently less favored than that depicted in Scheme 1.

The CID MS /MS spectrum of the anti-BaP $(9,10) \mathrm{DE}$ adduct of EGVYVHPV (angiotensin II antipeptide) is shown in Figure 2a. The two strongest signals in the spectrum, corresponding to $m / z 257$ and to the ion produced from the loss of the adducting moiety as a neutral molecule $\left([\mathrm{M}+\mathrm{H}-302]^{+}\right)$, show that cleavage between the anti-BaP$(9,10) \mathrm{DE}$ moiety and its point of attachment is the most favored product-ion pathway. Charge is retained preferably by the adducting moiety as indicated by the greater abundance of the $m / z 257$ ion. As a result of this competition for charge, the peptide sequence product ions are of low relative abundance. However, from the $a_{6}^{\text {*h }}$ and $a_{7}^{*}$ ions, one can deduce that the modified amino acid is His-6.

The proposed mechanisms for the genesis of the $m / z 257$ (anti-BaY(Y,10)DE adducting moiety) ion are shown in Schemes 1 and 2, respectively; the mechanisms for the adducted peptide [M+ $\mathrm{H}]^{+}$ion minus the adducting moiety are shown in Scheme 3. The peptide molecular ion $(\mathrm{m} / z$ 900.1) that lacks the anti$\mathrm{B} a \mathrm{P}(9,10) \mathrm{DE}$ moiety fragments further, giving rise to a spectrum that is a superposition of ions derived from adducted as well as unadducted peptides.

Other PAH diolepoxide adducts to peptides similarly exhibit dominant fragment ions that represent this moiety (Scheme 2) and depress the formation of the sequence characteristic peptide fragments. For example, adducts of anti-BaA(10,11)DE (II) exhibit an abundant fragment ion at $m / z 233$ (Figure 2c). The same holds for adducts of fluoranthene-diolepoxide [18], which give rise to an ion of $m / z$ 207. This peak 
<smiles></smiles>

$\mathrm{m} / \mathrm{z} 303$<smiles>C=C1C=C(O)C=CC1O</smiles>

$m / z$ 285*

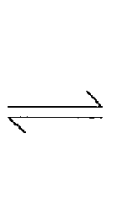<smiles>C=C1C=CC(=O)CC1O</smiles><smiles>CCCCCCCO</smiles><smiles>C=C1C=CC(=O)CC1=C</smiles>

$\mathrm{m} / \mathrm{z} 267^{*}$

Scheme 2. Pathway that produces ions from the anti-BaP(9,10)LE moiety.

dominates the region of the spectrum shown in ref 18 , but it was neither labeled nor discussed.

The peptide sequence fragment ions in the spectrum of anti-BaP(9,10)DE adducted DRVYIHPF (Figure 2b) [20] are more abundant, relative to the $\mathrm{m} / \mathrm{z}$ 257 ion, than for EGVYVHPV (Figure 2a). The $a_{6}^{*}-a_{8}^{*}$ ions indicate that the PAH triol is attached to His-6. Furthermore, the spectrum contains a complete series of $a_{2}-a_{8}$ ions. Both of these improved features are probably due to the presence of arginine near the $\mathrm{N}$-terminus of the former peptide. This strongly basic amino acid localizes the charge and increases the abundance of N-terminal product ions. At the same time, this charge localization favors the loss of the adducting moiety as a neutral species, thus giving rise to more abundant peptide fragment ions. As expected, the $\mathrm{CID}$ spectrum of the anti-BaA(10,11)DE adduct exhibits very similar features (Figure $2 \mathrm{c}$ ). However, the lower relative abundance of the $\mathrm{m} / z 233$ ion implies that cleavage of the adduct-peptide bond with retention of charge by the adducting moiety is less favored for the anti-BaA(10,11)DE moiety. Note that anti$\mathrm{B} a \mathrm{~A}(10,11) \mathrm{DE}$ lacks the bay-region resonance stabilization at $\mathrm{C}-11$ that is known to stabilize a positive charge

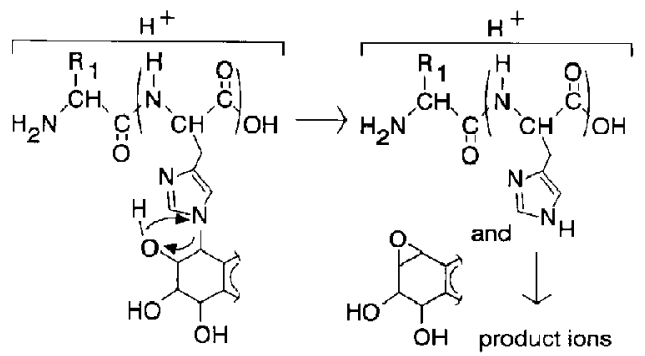

Scheme 3. Mechanism for the production of ions from the peptide portion of anti-BaP(9,10)DE adducts. An analogous mechanism applies for other PAH diolepoxide adducts.
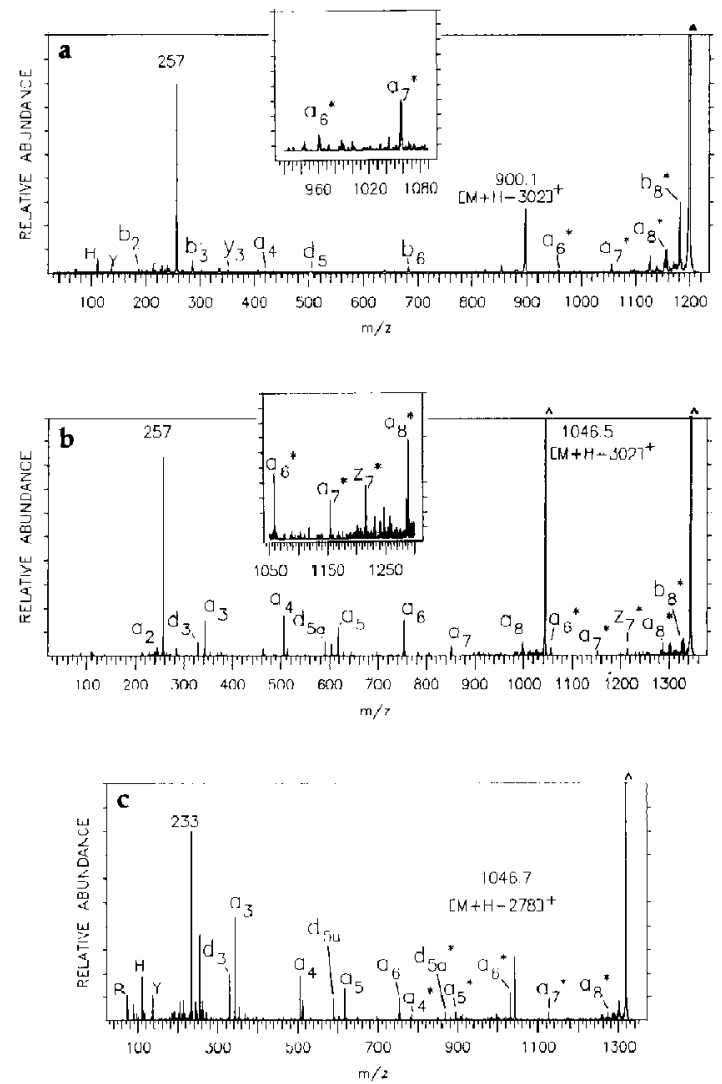

Figure 2. CID tandem mass spectra of (a) anti-B $a \mathrm{P}(9,10) \mathrm{DE}$ adducted LGVYVIII'V, $\left[\mathrm{M}+[1]^{+}-m / z 1202.5\right.$ (insert: 12.5-fold expansion of $y$-axis from $m / z$ 920-1080); (b) anti-BaP(9,10)DE adducted DRVYIHPF, $[\mathrm{M}+\mathrm{H}]^{+} m / z=1348.6$ (insert: 7.5-fold expansion of $y$-axis from $m / z 1050-1300$ ); (c) anti-BaA(10,11)DE adducted DRVYIHPF, $[\mathrm{M}+\mathrm{H}]^{+}=m / z$ 1324.8. In this and all other figure legends, the modified amino acid is indicated in bold. Product ions that contain the adducting moiety are labeled with an asterisk. 
at the analogous $\mathrm{C}-10$ on anti-BaP(9,10)DE [21]. Quantum mechanical calculations show that the cations produced by the hydrolysis of bay-region diolepoxides are more stable cations than those from nonbay-region diolepoxides [21-23]. The very small peaks labeled $a_{4}^{*}$, $d_{5 a}^{*}$ [28], and $a_{5}^{*}$ indicate that a minor by-product, probably the N-terminal anti-BaA(10,11)DE adduct, was formed during the synthesis. The notation $d_{n a}$ and $\mathrm{d}_{\mathrm{nb}}$ for amino acids with an unsymmetrically substituted $\beta$-carbon is analogous to that for $w_{n a}$ and $w_{n b}$ ions [28].

As Figures $2 b$ and $2 c$ indicate, localization of the charge on the peptide moiety increases the relative abundance of sequence characteristic peptide ions. It is by now well known [27, 29-31] that placing a fixed charge on either end of a peptide further directs the fragmentation process and that a positive charge localized at the $\mathrm{N}$-terminus is most effective. For this purpose, a trimethylammonium acetyl (TMAA) group is the optimal choice $[27,29,30]$.

The spectrum of anti-BaP(9,10)DE adducted TMAA-EGVYVHPV (Figure 3a) exhibits complete $a_{n}$ and $d_{n}$ ion series (except for glycine). The peptide product ions, particularly the important $a_{6}^{*}, a_{7}^{*}$, and $a_{8}^{*}$ fragments, are far more abundant than those observed in the CID spectra of PAH adducted peptides that do not bear a fixed charge (Figure 2a). The $m / z 257$ ion is still abundant but no longer dominates the spectrum.

The product ions shifted by $302 \mathrm{u}$ due to the adduct of $I$ are marked with an asterisk. As was observed with the underivatized peptide adducts, two processes operate to give rise to superposition of two sets of
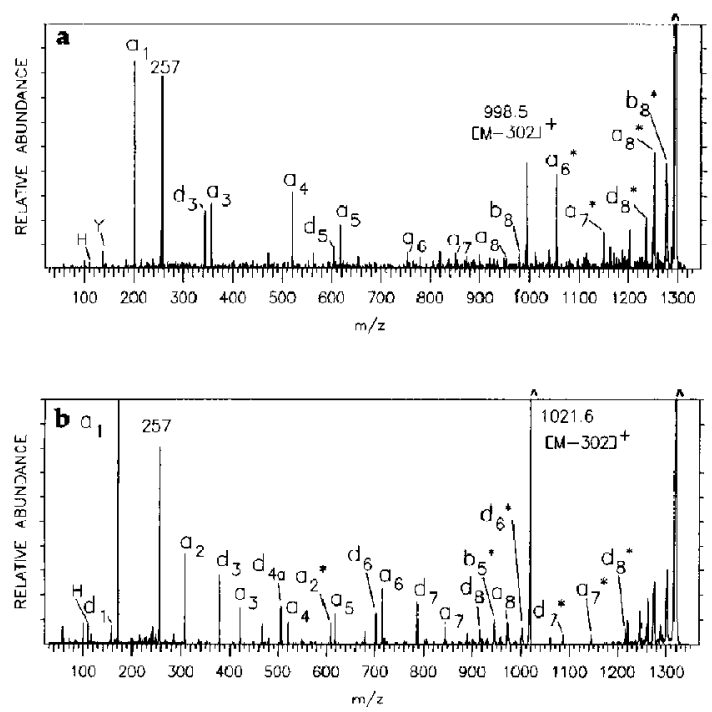

Figure 3. CID tandem mass spectra of (a) the trimethylammoniumacyl (TMAA) derivative of anti-B $a \mathrm{P}(9,10) \mathrm{DE}$ adducted EGVYVHPV, $[\mathrm{M}]^{+}=m / z$ 1300.9; (b) the TMAA derivative of anti-B $a \mathrm{P}(9,10) \mathrm{DE}$ adducted VHLTPVEK, $[\mathrm{M}]^{+}=m / z$ 1323.8. Product ions that contain the adducting moiety are labeled with an asterisk. $[\mathrm{M}]^{+}$denotes the precursor cation.

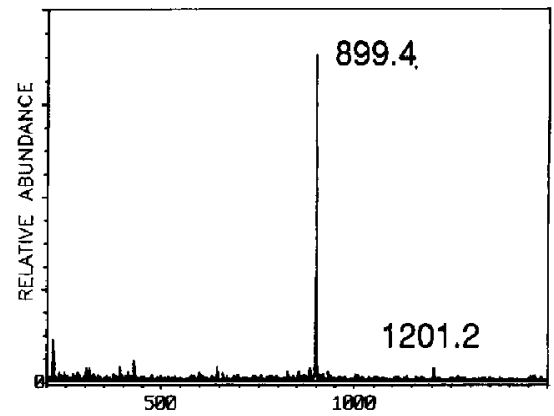

Figure 4. Constant neutral loss scan (302 u) indicating that the precursor ion is $m / z$ 1201.4, which is in good agreement with anti-BaP(9,10)DE adducted EGVYVHPV, $[\mathbf{M}+\mathbf{H}]^{+}=m / z$ (calculated) 1201.9.

sequence ions: one set is derived from the actual precursor ion of the adduct; the other set is derived from the precursor ion after loss of the diolepoxide moiety as a neutral molecule (analogous to Scheme 3). The $\mathrm{m} / \mathrm{z} 257$ ion may arise through formation of a zwitterionic peptide (i.e., leaving a negative charge on the imidazole ring) because the quaternary ammonium cation is immobile (analogous to Scheme 1). Similar results were obtained for the spectrum of anti$\mathrm{B} a \mathrm{P}(9,10) \mathrm{DE}$ adducted TMAA-VHLTPVEK (Figure $3 \mathrm{~b}$ ). For the sake of convenience, these TMAA derivatives were prepared at the 10-nmol level for this study of fragmentation behavior. For unadducted peptides, it has been shown that the derivatization procedure can be applied to as little as $100 \mathrm{pmol}$ and that a fraction corresponding to $40 \mathrm{pmol}$ of the product still resulted in CID spectra with high signal-to-noise ratio [32].

Because the CID spectra of all adducts exhibit a strong signal that corresponds to the loss of the adducting moiety as a neutral molecule (e.g., $302 \mathrm{u}$ from anti-B $a \mathrm{P}(9,10) \mathrm{DE}$ adducted peptides; see Scheme 3), all peptides with this modification can be detected by a 302-u constant neutral loss scan. The result for anti$\mathrm{B} a \mathrm{P}(9,10) \mathrm{DE}$ adducted EGVYVHPV, $[\mathrm{M}+\mathrm{H}]^{+}=m / z$ 1201.4, is shown in Figure 4. Although this spectrum was obtained with 1-2 nmol of sample, as little as 50 pmol still would result in a signal-to-noise ratio of 3:1. Such scans have been very useful in the screening of proteolytic digests for adducted peptides by using any of several diolepoxide metabolites, including isomers of $\mathrm{BaA}(10,11) \mathrm{DE}$, benzo[ $a]$ anthracene-trans-3,4-dihydrodiol-1,2-epoxide (anti), and benzo[ $b$ ]fluoranthenetrans-9,10-dihydrodiol-11,12-epoxide (anti) [33].

\section{Conclusions}

CID spectra of peptides adducted with PAH diolepoxide metabolites are dominated by ions produced from cleavage of the bond between the adducting moiety and the adducted side chain. When charge is retained by the adducting moiety, an abundant ion is observed at $m / z 257$ for anti-BaP(9,10)DE adducted peptides 
and $m / z 233$ for anti-BaA(10,11)DE adducted peptides. The ion produced by loss of the adducting moiety as a neutral species and corresponding to the mass-to-charge ratio value of the unadducted peptide $[\mathrm{M}+\mathrm{H}]^{+}$ion is usually less abundant. The loss of the metabolite moiety is quite useful for identifying adducted peptides by using constant neutral loss scans. The abundance of the metabolite ion reduces the intensity of peptide fragment ion signals, but conversion of the adducted peptides to their trimethylammoniumacyl derivatives is useful for increasing the abundance of peptide fragment ions.

\section{Acknowledgment}

The work was supported by The National Institutes of Health (grant numbers NIEHS ES04675, NIH GM05472, and RR00317).

\section{References}

1. Shoental, R. In Polycycic Hydracarbons, Vol. 1; Clar, E., Ed.; Academic Press: London, 1964; pp 133-160.

2. Stenberg, U.; Alsberg, T.; Westerholm, R. Environ. Heallh Perspect. 1983, 47, 53-63.

3. Jensen, T. E.; Hites, R, A. Anal. Chem. 1983, 55, 594-599.

4. Hites, R. A.; McVeety, B. D. Atmos. Environ. 1988, 22, 511-536.

5. Bjorseth, A.; Dennis, A. J., Eds. Polynuclear Aromatic Hydrocarbons: Chemistry and Biological Effects; Batelle Press: Columbus, $\mathrm{OH}, 1980$.

6. Guengerich, F. P. Pharmacol. Ther. 1992, 54, 17-61.

7. Miller, E. C.; Miller, J. A. Cancer 1981, 47, 2327-2345.

8. Hinson, J. A.; Roberts, D. W. Anrt. Rev. Pharmacol. Toxicol. 1992, 32, 471-510.

9. Skipper, P. L.; Tannenbaum, S. R. Carcinogenesis 1990, 11, 507-518.

10. Naylor, S.; Gan, L.-S.; Day, B. W.; Pastorelli, R.; Skipper, P. L.; Tannenbaum, S. R. Chem. Res. Toxicol. 1990, 3, 111-117.

11. Dipple, A. In Polycyclic Hydrocarbons and Carcinogenesis; Harvey, R. G. Ed.; ACS Symposium Series 283; American Chemical Society: Washington DC, 1985; pp 1-17.

12. Cavalieri, E. L.; Rogan, E. G. Pharmacol. Ther, 1992, 55, 183-199.

13. RamaKrishna, N. V. S.; Gao, F.; Padmavathi, N. S.; Cavalieri, E. L.; Rogan, E. G.; Gross, M. L. Chem. Res. Toxicol. 1992, 5, 293-302.
14. Devanesan, P. D.; RamaKrishna, N. V. S.; Todorovic, R.; Rogan, E. G.; Cavalieri, E. L.; Jeong, H.; Jankowiak, R.; Small, G. J. Chem. Res. Toxicol. 1992, 5, 302-309.

15. Day, B. W.; Skipper, P. L.; Zaia, J.; Tannenbaum, S. R. J. Am. Chem. Soc. 1991, 113, 8505-8509.

16. Skipper, P. L.; Naylor, S.; Gan, L.-S.; Day, B. W.; Pastorelli, R,; Tannenbaum, S. R. Chem. Res. Toxicol. 1989, 2, 280-281.

17. Day, B. W.; Skipper, P. L.; Rich, R. H.; Naylor, S.; Tannenbaum, S. R. Chem. Res. Toxicol. 1991, 4, 359-363.

18. Hutchins, D. A.; Skipper, P. L.; Naylor, S.; Tannenbaum; S. R. Cancer Res. 1988, 48, 4756-4761.

19. Kaur, S.; Hollander, D.; Haas, R.; Burlingame, A. L. J. Biol. Chem. 1989, 264, 16981-16984.

20. Zaia, J,; Biemann, K. Proceedings of the 40th ASMS Conference on Mass Spectrometry and Allied Topics; Washington, DC, 1992; pp 1577-1578.

21. Lowe, J. P.; Silverman, R. D. I. Mol. Struct. (Theochem) 1988. $179,47-81$.

22. Lehr, R. E,; Kumar, S.; Levin, W.; Wood, A. W.; Chang, R. L.; Conney, A. H.; Yagi, H.; Sayer, J. M.; Jerina, D. M. In Polycyclic Hydrocarbons and Carcinogenesis; Harvey, R. G., Ed.; ACS Symposium Series 283; American Chemical Society: Washington DC, 1985; pp 63-84.

23. Lowe, J. P.; Silverman, B. D. J. Am. Chem. Soc. 1981, 103, 2852-2855.

24. Annan, R. S.; Giese, R. W.; Vouros, R. Anal. Biochem. 1990, 191, 86-95.

25. Wolf, S. M.; Annan, R. S.; Vouros, P.; Giese, R. W. Biol. Mass Spectrom. 1992, 21, 647-654.

26. Sato, K.; $\Lambda$ sada, R.; Ishihara, M.; Kunihiro, F.; Kammei, Y.; Kubota, E.; Costello, C. E.; Martin, S. A.; Scoble, H.; Biemann, K. Anal. Chem. 1987, 59, 1652-1659.

27. Wetzel, R.; Halualani, R.; Stults, J. T.; Quan, C. Bioconi. Chem. 1990, $2,114-122$.

28. Johnson, R. S.; Martin, S. A.; Biemann, K.; Stults, J. T.; Watson, J. T. Anal. Chem. 1987, 59, 2621-2625.

29. Vath, J. E; Biemann, K. Int. J. Mass Spectrom. Ion Processes 1990, 100, 287-299.

30. Zaia, J.; Biemann, K. Proceedings of the 41st ASMS Conference on Mass Spectrometry and Allied Topirs; San Francisco, CA, 1993; pp 358a-358b.

31. Wagner, D. S.; Salari, A.; Gage, D. A.; Leykam, J.; Fetter, J.; Hollingsworth, R.; Watson, J. T. Biol. Mass Spectrom. 1991, 20 419-425.

32. Stults, J. T.; Lai, J.; McCune, S.; Wetzel, R. Anal. Chem. 1993, 65, 1703-1708.

33. Zaia, J. Ph.D. Dissertation, Massachusetts Institute of Technology, 1993. 